\title{
Lip and Oral Cavity Cancer Pathologic Regional Lymph Nodes TNM Finding v7
}

National Cancer Institute

\section{Source}

National Cancer Institute. Lip and Oral Cavity Cancer Pathologic Regional Lymph Nodes

TNM Finding v7. NCI Thesaurus. Code C88949.

A pathologic finding about one or more characteristics of lip and oral cavity cancer,

following the rules of the TNM AJCC V7 classification system as they pertain to staging of regional lymph nodes. 